\title{
ПРОБЛЕМЫ РАЗВИТИЯ РЫНКА ФАКТОРИНГОВЫХ УСЛУГ
}

\author{
(c) 2021 Петрова О.А. \\ старший преподаватель Департамента бизнес-аналитики \\ Финансовый университет при Правительстве Российской Федерации, Россия, Москва \\ E-mail: OAPetrova@fa.ru
}

Рынок факторинговых услуг развивается бурными темпами в России. Так, к концу февраля 2019 года Ассоциация факторинговых компаний (далее - АФК) опубликовала статистические показатели деятельности российских факторов по итогам 2018 года. По данным АФК рынок достиг высшей отметки по величине принятого кредитного риска, объему финансирования бизнеса и росту клиентской базы, чему способствовало сотрудничество с крупными дебиторами [4].

Ключевые слова: учет, анализ, аудит, факторинг, факторинговые услуги

Лидирующее место на рынке по абсолютному показателю прироста портфеля занял ВТБ Факторинг. По итогам 2018 года его факторинговый портфель (далее - портфель) достиг 215 млрд. рублей, тем самым возрос на $60 \%$ по сравнению с предыдущим годом. Финансирование в 2018 году получили более тысячи клиентов на сумму свыше 600 млрд. рублей, что в 1,5 раза больше по сравнению с показателем за 2017 год. Рыночная доля ВТБ Факторинг по факторинговым услугам за 2018 год увеличилась до 35\% [3]. Рост факторинговых услуг продолжался и в 2019 году, но COVID-кризис внес свои поправки и затормозил развитие рынка факторинговых услуг в 2020-2021 годах.

Наибольшую долю в портфеле занимает безрегрессный факторинг, при котором риски неплатежа со стороны контрагентов полностью покрываются факторинговой компанией. Треть сделок по факторингу в прошлом году была реализована в рамках новых программ финансирования кредиторской задолженности.

Ниже рассмотрим факторы, сдерживающие развитие факторинга в России, представим их на рисунке 1 в составе трех основных групп.

Таким образом, можно сделать вывод, что между факторами, ограничивающими развитие факторинговых операций в стране, следует выделить общеэкономические факторы, определяющие особенности экономики страны, а также факторы, влияющие на спрос и предложение на рынке факторинговых услуг. Недостаточный

\begin{tabular}{|c|c|}
\hline $\begin{array}{c}\text { Факторы, связанные со } \\
\text { структурными особенностями } \\
\text { предпринимательства в России и } \\
\text { общеэкономическими факторами }\end{array}$ & $\begin{array}{l}\text { •Сокращение доходов населения и выручки } \\
\text { предпринимателей } \\
\text { •Рост кредитных рисков } \\
\text { •Неблагоприятная эконичическая ситуация }\end{array}$ \\
\hline $\begin{array}{c}\text { Факторы, связанные с } \\
\text { особенностями факторинга с } \\
\text { точки зрения клиента }\end{array}$ & $\begin{array}{l}\text { •Высокая стоимость факторинга } \\
\text { •Непрозрачная система ценообразования } \\
\text { •Недостаточная финансовая грамотность и недоверие } \\
\text { к факторинговым компаниям } \\
\text { •Необходимость раскрытия информации о денежных } \\
\text { потоках }\end{array}$ \\
\hline $\begin{array}{c}\text { Факторы, связанные с } \\
\text { особенностями факторинга с } \\
\text { точки зрения компании-фактора } \\
\text { и законодательства }\end{array}$ & $\begin{array}{l}\text { •Сложность оценки кредитоспособности дебитора } \\
\text { •Отсутствие регламентированных требований к оценке } \\
\text { кредитоспособности клиентов } \\
\text { •Ограничение развития факторинга в сфере } \\
\text { государственных контрактов }\end{array}$ \\
\hline
\end{tabular}

Рисунок 1. Факторы, сдерживающие развитие факторинга в Российской Федерации 
спрос на услуги факторинга, в свою очередь, приводит к дефициту клиентской базы и способствует росту принимаемых факторами рисков за счет сотрудничества с менее надежными контрагентами. При этом следует отметить нежелание принимать высокие риски в связи с существующими на сегодняшний день проблемами в сфере оценки кредитоспособности клиентов и способов минимизации потерь. С нашей точки зрения, на текущий момент времени, первоочередной задачей для развития рынка факторинговых услуг является стимулирование спроса на факторинговое финансирование со стороны клиентов с хорошим уровнем кредитоспособности.

Приведем некоторые рекомендации, исходя из проблем, имеющихся на рынке факторинговых услуг.

1. Высокая стоимость факторинга по сравнению с аналогичными банковскими продуктами.

Стоимость факторинга определяется двумя составляющими - стоимостью финансирования для факторинговой компании, которая зависит от ключевой ставки Банка России, и платой за принимаемые риски. В связи с тем, что факторинговые операции изначально более рискованные, чем простое банковское кредитование из-за отсутствия залогов и более лояльных требований к финансовому состоянию клиентов, стоимость таких услуг, соответственно выше.

Полагаем, что для повышения привлекательности факторинга и снижения стоимости для клиента, следует использовать дифференцированный подход, предполагающий прямую зависимость между стоимостью услуги и рисками по сделке. Следует отметить, что в настоящее время указанная система уже практикуется многими компаниями, однако, как правило, дифференцирована только ставка процента за кредитные средства. Ставка комиссии за оказание факторинговых услуг при этом не зависит от рисков по контрагенту, а если и зависит, то устанавливается статично для каждого лимита финансирования и не дифференцируется в зависимости от фактического объема сделок переуступки в натуральном выражении, также не используется зависимость ставки комиссии от фактического срока отсрочки платежа.

2. Непрозрачная система ценообразования.

В качестве второго сдерживающего фактора выделена непрозрачность системы ценообразо- вания по факторинговым соглашениям. Полагаем, что базовые тарифы, в том числе зависимость ставки за пользованием заемными средствами от кредитоспособности заемщика и дебитора, а также варианты матрицы комиссионного вознаграждения, должны быть размещены на официальном сайте факторинговых компаний.

Кроме того, целесообразна разработка упрощенного калькулятора расчета стоимости, который позволит самостоятельно рассчитать приблизительную стоимость финансирования и даст информацию обо всех возможных факторах, влияющих на цену [1].

3. Недостаточная финансовая грамотность и недоверие к факторинговым компаниям.

Данная проблема частично решается увеличением прозрачности ценообразования, являющегося ключевым фактором при выборе способа заимствования. Однако, помимо стоимости факторинговых услуг, клиентов интересует надежность компании и схема сделки со всеми возможными нюансами.

Для увеличения прозрачности деятельности факторинговых компаний рекомендуется размещение финансовой отчетности и ключевых показателей на официальном сайте. Это может стать первым шагом, повышающим уровень доверия между компаниями- факторами и клиентами.

Тем не менее, на наш взгляд, для усиления прозрачности рынка в целом, рассмотренные требования должны быть закреплены на уровне законодательства. Несмотря на то, что в настоящее время деятельность факторинговых компаний не регламентируется отдельным законодательным актом, и не поднадзорна финансовому регулятору, с нашей точки зрения, необходимо урегулирование факторингового рынка - ведение реестра факторинговых компаний, закрепление отдельных требований к ним в отношении раскрытия информации.

4. Необходимость раскрытия информации о денежных потоках клиентов.

Данная проблема решается повышением доверия между клиентами и факторами, гарантированием коммерческой тайны со стороны последних. Иными словами, клиент должен понимать, что факторинговая компания не осуществляет раскрытие предоставляемой в ее адрес информации третьим лицам, в том числе налоговым органам. «Вопрос раскрытия управленческой информации также актуален при 
сотрудничестве предприятий и кредитных организаций, при этом банк гарантирует, что предоставляемая информация о денежных потоках и контрактах клиента является банковской тайной» [2]. Полагаем, что рассмотренное выше повышение прозрачности деятельности факторинговых компаний повысит уровень доверия к ним со стороны клиентов.

«Для осуществления всех предлагаемых рекомендаций необходима унифицированная система оценки кредитного риска, то есть все факторы, участвующие в программе должны заранее определять максимальный порог риска, который они готовы принять, а риск должен рассчитываться по единой методологии, исключающей существенное влияние субъективных факторов» [5]. Выполнение данного условия необходимо, поскольку в противном случае факторинговые компании смогут использовать предлагаемую программу для покрытия собственных рисков, которые они в любом случае готовы были принять. Кроме того, это соответствует предложенным выше рекомендациям относительно регулирования общих подходов к оценке кредитоспособности в целях повышения надежности рынка в целом и предотвращения дефолтов.

Таким образом, на основе выделенных сдерживающих факторов развития факторинга в России, в статье предложены основные рекомендации по повышению роли факторинга в экономической системе. В первую очередь на государственном уровне необходима реализация мер по усилению прозрачности факторингового рынка, раскрытию информации о деятельности компаний-факторов, в том числе о системе ценообразования. В сфере государственного регулирования факторинговой деятельности требуется закрепление требований к принимаемым рискам и раскрытию информации, разработка норм по ведению базы факторинговых историй. Также важной мерой для стимулирования развития факторинга в России является также разработка полномасштабной программы поддержки субъектов малого предпринимательства. Это позволит повысить доступность факторинговых услуг для этой группы организаций, и соответственно, увеличит обороты на рынке.

\section{Библиографический список}

1. Бадалов Л.А, Сысоева А. А. «Роль системы банковского контроллинга в финансировании предпринимательской деятельности» - М., 2017.

2. Ивасенко А.Г., Никонова Я.И. «Факторинг» - Кнорус, 2018. - 102 с.

3. Ассоциация факторинговых компаний [Электронный ресурс] - Режим доступа: http://asfact.ru;

4. Официальный сайт ВТБ Факторинг [Электронный ресурс] - Режим доступа: https://www.vtbf.ru;

5. Эксперт РА [Электронный ресурс] - Режим доступа: https://raexpert.ru/researches/factoring/2016/part1/\#1. 